\title{
Female Technology Leaders Overcome Barriers to Climb the US Industry Ladder
}

\author{
Emily E. Bell \\ Fulton County Schools \\ 6201 Powers Ferry Road NW, Atlanta, GA 30339, USA \\ Rudo E. Tsemunhu \\ Valdosta State University \\ 1500 N. Patterson St. \\ Valdosta, Georgia 31698, USA \\ James Martinez \\ Valdosta State University \\ 1500 N. Patterson St. \\ Valdosta, Georgia 31698, USA \\ Herb Fiester \\ Valdosta State University \\ 1500 N. Patterson St. \\ Valdosta, Georgia 31698, USA \\ Danielle J. Alsandor \\ University of the Incarnate Word \\ 4301 Broadway Street \\ San Antonio, Texas 78209, USA
}

\begin{abstract}
Women represented $57 \%$ of the labor force, but only $20 \%$ in the technology industry (United States Labor Department Bureau of Labor Statistics, 2015). Therefore, we utilized narrative inquiry research design with feminism and gender role incongruity theories as theoretical frameworks to investigate five women's experiences becoming leaders of major technology organizations. We collected data from interviews and documents. Data analysis revealed four major themes: climb your ladder, know your worth, discover your career, and nurture your vision. The findings suggested that the primary barriers for women entering and staying in the technology field were removed by intrinsic motivation augmented by personal persistence, passion for learning, creativity, and efficiency. The female technology leaders in this study shared valuable, diverse leadership perspectives that may benefit male technology leaders. All participants exhibited an ability to nurture team members and organization goals using soft skills to ameliorate the rigid and fast-paced technology industry.
\end{abstract}

Key words: Female workers, technology, gender roles, feminism, Critical Race Theory

In the late-20th century, United States employment opportunities shifted from industrial to information computing (Tripathy, 2017). According to Beckhusen (2016), there were 450,000 employees in American information technology jobs in 1970. The United States technology industry increased by 3\% in 2016, bringing the total number of workers to seven million (CompTIA, 2017). Initial technology job growth was impacted by the introduction of affordable home and work computers in the 1960s and 1970s, but the employment opportunities increased tenfold between 1970 and 2014 as businesses harnessed the benefits of increased productivity (Beckhusen, 2016). According to Rodriguez (2017), many current technology industry employees are immigrants because the United States does not have enough natural born citizens to fill the positions. U.S. Department of Labor (2015) projections indicated American universities will only produce enough graduates to fill $29 \%$ of technology specialists' jobs.

America does not have enough skilled talent to fill the jobs made available in the growing field of technology and there are disproportionately low numbers of female technology workers and female technology leaders participating in technology careers (Ashcraft, McLain, \& Eger, 2016; Moye, 2017; United States Labor Department, 2015; Zweben \& Bizot, 2016). The United States Department of Labor Bureau reported that women currently represent $57 \%$ of the workforce. However, women face a significant gender gap as evidenced by a current $25 \%$ participation rate in the field of technology and 6\% participation as technology leaders (Ashcraft, McLain, \& Eger, 2016; Harvey Nash CIO Survey, 2015; United States Labor Department, 2015). 
Trends in the last twenty years indicate a steady decline in the percentage of females in technology (Ashcraft, McLain, \& Eger, 2016).

The purpose of this study was to examine the experiences of identified females in their efforts to participate in technology careers as workers and become technology leaders. The primary research questions included:

1. What are the experiences of identified female leaders prior to participating in technology careers as workers and leaders?

2. What barriers, if any, did identified technology female leaders encounter in their efforts to participate in technology careers as workers and become technology leaders?

3. What strategies did identified female technology leaders use in their efforts to participate in technology careers as workers and leaders?

Feminist theory and the gender role incongruity theory undergird the theoretical framework and ultimately provided a lens for the data analysis (Daiute, 2014; Denzin \& Lincoln, 2005). Feminist theory is the philosophical discourse which aims to understand the nature of gender inequality. This theory is based on three basic principles: first, the relationship between men and women has almost always been unequal and oppressive; second, all known societies have been patriarchal; and third, all major social institutions have been characterized by male dominance (economy, political systems, family and religion). Feminist theory explores both inequality in gender relations, and the constitution of gender was used to explain women's underrepresentation in technology leadership positions (Carlson \& Ray, 2011).

\section{Gender Role Incongruity}

Women who fail to professionally advance are caught below the "glass ceiling," a term associated with workplace gender discrimination (Sipe, Johnson \& Fisher, 2009). Sipe et al. (2009) reported five reasons that prevent women from breaking through the glass ceiling: workplace discrimination, insufficient mentoring, stereotyping, family conflicts, and inadequate funding. They indicated feminine systems theorists illuminated the issues surrounding the glass ceiling to eradicate the problem in organizations. However, men in decision making positions continue to hire males and maintain stereotypical notions about the value of women in the workplace, which hinder female advancement beyond the glass ceiling (Wentling \& Thomas, 2009). McEldowney, Bobrowski and Gramberg (2009) suggested the glass ceiling was no longer a concern, but rather the more refined idea of role incongruity which had far reaching implications beyond basic stereotyping.

Eagly and Karau (2002) initially examined the theory of role incongruity in conjunction with males or females employed in occupations that were traditionally not associated with their societal role. Based on these social roles, women are typically described and expected to be more communal, relations-oriented, and nurturing than men, whereas men are believed and expected to be more assertive and independent than women (Cejka \& Eagly, 1999; Eagly \& Carli, 2007; Eagly \& Karau, 2002; Layne, Vostral, \& Boyer, 2010; Paustian-Underdahl, Walker, \& Woehr, 2014). Brumels and Beach (2008) later defined role incongruity as the inability to meet the obligations, personal skills, morality or expectations set by society for that role. Role incongruity not only was an evaluation based on alignment with typical social roles made by peers, but it was also an influential factor in how females viewed their capabilities. Henning and Weidner (2008) contend a female in a leadership role may experience selfinflicted stress because the role requirements for leadership conflicted with typical feminine role requirements. Grounded in the family perception of the female role, women tend to seek those career fields that are nurturing, socially important, and extensions of the home (Schmidt, 2012).

Schmidt (2012) examined the strict southern normalization of a woman's role in society as analyzed in the history curriculum in South Carolina. He found that the curriculum included very few women in history, and the portrayal of the included women was framed by the Deep South view of women as homemakers. In another study, Lublin and Brewer (2003) found wider pay gaps and poor workplace treatment for the female workers of southern states. They compared the status of women in the United States based on a number of categories including employment and earnings. Each state was rated with a letter grade, but none of the southern states were given an overall grade higher than a C-. This low score indicates a huge gender gap in the Southern region of the USA.

On a larger geographical scale, Layne, Vostral, and Boyer (2010) compiled a number of essays related to feminist technology which stated, Euro-American culture associated technology with masculinity and nature with femininity. Technical knowledge domains are congruent with the male role which prevents women from wanting to be in the field and men accepting women in the field (Layne et al., 2010). Eagly and Carli (2007) dismissed the metaphor of glass ceilings as an accurate portrayal of women's professional advancement now that there are female chief executives in various industries. To better describe the continued barriers at various stages in advancement, they referred to female progression as a labyrinth which has multiple dead ends, but with persistence, awareness, and analysis can be navigated (Eagly \& Carli, 2007). 
Saucerman and Vasquez (2014) reported on a situation involving the American company, Mattel. As reported by the New York Times, Mattel had several sexist infractions exhibited in a few of their Barbie dolls and accompanying books (Mattel Says, 1992). In 1992, one of their dolls had a string that when pulled would trigger a recording that said, "Math class is tough. Party dresses are fun" (Mattel Says, 1992). Mattel pulled the doll off the shelves amid public complaints stereotyping girls as inferior in math (Mattel Says, 1992). In 2010, Mattel released the Computer Engineer as the 126th career doll in their "I Can Be" Barbie doll line (Chang, 2010, p. 1). The Barbie Computer Engineer doll had an accompanying book which portrayed a conversation between Barbie and her friend about the new computer game Barbie was designing (Lorenz, 2014). As the conversation progressed, Barbie clarified that she was only doing the design because she needed the boys' help to make the designs turn into a real game (Lorenz, 2014). Kuther and McDonald (2004) argued that toys can affect central identity and gender role association, especially Barbie which has become an iconic American symbol. Environmental and educational influences determine a female's ability to step outside of traditional expectations, (Saucerman \& Vasquez, 2014). Moreover, interaction with women from a variety of backgrounds and in positions of power allowed females to visualize non-traditional roles (Richman, Vandellen, \& Wood, 2011).

Gross (2003) defined feminism as "freedom from the prison of gender roles" (p. 8). She indicated both male and female gender roles are confining culturally imposed prisons. Furthermore, she argued that traditional female gender roles are especially destructive of a woman's wellbeing in that women were exclusively expected to nurture the family without equal responsibility of those tasks to males which secluded women and belittled their competence. Gross firmly believes feminism is the effort to change oppressive gender roles.

In another study Suter and Toller (2006) examined the characteristics of feminists as "independent", "not afraid to be alone," and "having a different way of thinking" (p. 139). They also alluded to the duality of being a feminist who is capable of being feminine. One participant reported that a woman was capable of being "soft and nurturing" but still able to "stand up" for their viewpoint (p. 139). Suter and Toller concluded that feminism and female gender roles were synonymous and that the feminist movement was still hindered by societal gender role assignments.

Eagly examined workplace prejudice caused by gender role incongruity (Hogg \& Knippenberg, 2003). Hogg and Knippenberg (2003, p. 89) found a "convergence of the psychological attitudes of women and men in traditionally masculine domains" in which women are becoming more masculine in order to assimilate in male dominated environments. Conversely, they noted leadership styles as migrating from authority figures using dominance in the workplace to authority figures using nurturing techniques of empowerment and authentic communication. Hogg and Knippenberg (2003) contend this convergence showed leadership as female stereotypical and less male authoritarian, and concluded that a possible androgynous middle ground exists wherein the "characteristics ascribed to women match leadership roles as well as those ascribed to men" (Hogg \& Knippenberg, 2003, p. 90).

\section{Feminist Theory}

Eagly and Karau, (2002); Henning and Weidner, (2008); Saucerman and Vasquez, (2014); Suter and Toller, (2006) examined feminism theories and gender roles separately and synonymously as field experts suggest they are one and the same. Gross (2003) defined feminism as the pursuit of breaking free from gender roles. Feminism theories and gender role incongruity intersect in their focus on the female experience and were used to help understand alternate ways that female technology leaders may perceive their experiences (Eagly \& Karau, 2002; Gray et al., 2015).

A common thread in feminism theory exists in the view that the law lacks equal attention to women relative to men (Armani, 2013). The researchers examined gender equity policies and laws to determine the extent to which political legislation and government support have impacted gender specific issues (Fifty Years after the Equal Pay Act, National Equal Pay Task Force, 2013). The goal was to include information to explore the history and current condition of the female experience and to determine the extent to which the law supports or opposes females with specific emphasis on workplace legislation.

\section{The United States Technology Industry}

United States technology industry interest groups pushed policy makers to allow increased work visas to enable them to hire skilled talent outside of the United States (Hickey, 2013). More Americans could fill the skills gap, but the industry overlooks talented women, African Americans and Hispanics (Rodriguez, 2017). Ashcraft et al. (2016) reported the need for American education institutions and employers to employ specific strategies to harvest female talent in technology and narrow the skills gap in the United States. Zweben and Bizot (2016) reported that $15.7 \%$ of computing related Bachelor degrees were awarded to females. Twenty-five percent of computing occupations belonged to women (Ashcraft, McLain, \& Eger, 2016). The New York Times, as reported by Miller (2013), observed the doors to the expanding technology field "remain virtually closed to women" (p. 1). 
Moreover, women are absent from technical managerial positions. Gettings, Johnson, Brunner, and Frantz (2007) noted equal representation in technical leadership would take over 40 years at the current pace. The Harvey Nash CIO Survey (2015) revealed that the percentage of female Chief Information or Technology Officers in the United States as $6 \%$. Huge technology corporations like Google reported, " $17 \%$ of their technical staff was represented by females" even though "women constitute half of the United States working force" (Whitney \& Ames, 2014, p. 28). Despite federal grants for gender representation in non-traditional employment, women lacked equal workplace representation in technical fields (Kuruvilla, 2014).

\section{Common Barriers in the Workplace}

Grounded in the family perception of the female role, women tend to seek those career fields that are nurturing, socially important, and extensions of the home (Schmidt, 2012). Schmidt (2012) investigated the strict southern normalization of a woman's role in society as analyzed in the history curriculum in the South Carolina. He found that the curriculum included very few women in history and the portrayal of the included women was framed by the Deep South view of women as homemakers.

Powell and Sang (2015) contend that women who worked outside the home in male dominated fields like technology and engineering reported many common issues. They argued that exclusion from events, projects, or training opportunities limited the scope of experience and contributed to consequent promotion by-pass. This issue is the most difficult to overcome. Other barriers include prohibitive advancement and unequal pay (De Welde et al., 2007). Ultimately, Cukier (2009) blamed a deficit in support systems for women who desire a balance of work and family life for the absence of women in the challenging, time-consuming technology sector.

Orser, Riding, and Stanley (2012) conducted a study to determine career challenges and response strategies of women in the advanced technology sector. They recruited 195 women to participate in an online survey and yielded 115 responses. Most participants reported personal barriers such as the perception that the time-consuming technology field did not allow for a balance of work and family life. Participants also reported workplace barriers including exclusion from events, projects, or training opportunities also limited the scope of experience and contributed to consequent promotion by-pass. One participant cited mistrust by a male manager who denied her a professional learning opportunity because he felt she was likely to use sick leave or leave the company due to family reasons. Participants who were not given career advancement opportunities simply left and sought other employment (Orser et al., 2012). Chou et al. (2012) described the exodus of females from science and technology fields in different stages of their careers due to personal grievances and ultimate resignations as the "leaky pipeline," (p. 159). Demaiter and Adams (2009) stated female technology leaders should be constantly apprised of gender disproportionality in the technology field to avoid unconsciously ignoring the issue because they have managed to be successful. Consistent awareness would allow female technology leaders with influence an opportunity to affect change and educate future generations of women interested in technology as a career and it would help to break the glass ceilings kept in place by women who are just trying to survive (Demaiter \& Adams, 2009).

Demaiter and Adams (2009) referred to women behaving as conceptual men at work to blend in with the male dominated environment. These women would assimilate by compartmentalizing life at work which included dropping feminine ideals and dressing to adopt masculine behaviors and activities like golf (Demaiter \& Adams, 2009). These findings may suggest women can be part of the problem because women tend to conform to the male dominated organization (Miller, 2004). Miller (2004) explored experiences of women engineers and noted female assimilation to masculine systems as unintentional reinforcement of masculine hierarchy. Women in this study denied that gender is salient and avoided female actions like displays of emotion or empathy towards colleagues.

\section{Problem Solving Strategies}

Richman, Van Dellen, and Wood (2011) cited the importance of a female role model as the primary strategy to overcome feelings of inadequacy for a girl considering a high-tech field. Powell et al. (2012) reported female career decisions centered on other influential people, social and financial rewards, and the potential enjoyment the career could provide. Saucerman and Vasquez (2014) defined influential people as parents, teachers, peers and, media personalities. The combination of positive reinforcement from these people and a growth mindset showed statistical gains in female participation in technical fields (Saucerman \& Vasquez, 2014). Instructional strategies like collaborative learning, project based learning, and relevant career connections were cited as countermeasures for negative perceptions (Dugan, Fath, Howes, Lavelle, \& Polanin, 2013). Also, noted in the study was the inclusion of leadership efficacy enhancements directed towards persistence and career success, which included philanthropic endeavors, mentoring, and club leadership activities (Dugan et al., 2013). Leadership development stimulated inherent attitudes conducive to technical fields like sustained curiosity, love of learning, and the need to make valuable contributions (Wentling \& Thomas, 2009). With these problem-solving strategies in place, females were more likely to choose technology fields for their program of study. 


\section{Methods}

The research questions connect with a qualitative dynamic narrative inquiry research design. According to Ary et al. (2014), narrative inquiry allows the researcher to examine the participants' past with the present to gain understanding of the essential experience. Study limitations must be identified in qualitative research to provide credibility and trustworthiness (Patton, 2005). Purposive sampling and the Seidman's interview process yielded a body of rich data, but limited number of participants impacts the generalization of study results (Patton, 2005; Siedman, 2006). The female technology respondents, Anne, Celine, Grace, Margaret, and Summer (pseudonyms to protect their identity), held chief level positions in the technology domain. Specifically, they included four Chief Information Officers who ranged in technology leadership experience from 11 to 27 years. The fifth participant was a Chief Executive Officer of a technology company with 10 years of experience. All the women were Caucasian. Each of the women worked in different industries which included an international hotel, education organization, law firm, insurance company, and a privately-owned technology industry. The study did not address other industries nor different ethnicities. As a result, transferability to groups not represented could be a study limitation. Interviews following Seidman's (2013) three step interview process was used to collect rich, meaningful data in their natural setting. Purposive sampling was used to enlist female technology leaders currently working in that area. Table 1 includes basic information for the five study participants.

Table 1: Participant Demographic Information

\begin{tabular}{llllll}
\hline Pseudonym & Gender & Ethnicity & Age & Years in Technology Leadership & Current Position \\
\hline Anne & Female & White & 67 & 16 & Chief Information Security Officer \\
Grace & Female & White & 57 & 10 & Chief Executive Officer \\
Summer & Female & White & 57 & 11 & Chief Information Officer \\
Celine & Female & White & 53 & 27 & Chief Information Officer \\
Margaret & Female & White & 45 & 16 & Chief Information Officer \\
\hline
\end{tabular}

The following brief participant profiles provide background narratives including information regarding their family, school, and work experiences.

Anne was a 66-year-old, wife and mother of one daughter. At the time of the interview, Anne was in her 39th year of her working career and had 16 years in technology leadership as her current position was Chief Information Security Office for an international hotel organization. Anne was born in Atlanta but graduated from college in Minnesota and began her career there. Her dad was a math and science teacher who later worked for a major computing company. She referred to her mom as a "traditional homemaker." She had two sisters and two brothers with whom she learned "team skills, conflict management, and loyalty." Anne's career choice was inspired by her father who she discussed throughout the interview process. Anne's career path included employment with several very large and well-known national and international companies within the telecommunications, financial services, and hospitality industries. Her job roles included systems design and network specialist; and eventually, an executive encouraged her to pursue a management career path.

Grace was a 57-year-old woman, married with a son and a daughter. At the time of the interview she had been the Chief Executive Office and co-owner of a technology company for 10 years, but she had previously worked fulltime as a lawyer for nine years. Grace was born in the Washington D.C. area and she had two siblings. Her parents were both educators in the local school district. As a child, Grace was "a helper...Tom Boy... [and] Daddy's girl." Grace credited her dad, a school principal, as a primary influence in her life and career. In 2007, Grace and her husband started their privately-owned family technology company. As a startup entrepreneur with limited funding, Grace had to learn many aspects of running a business. Grace warned the survival of a woman in technology depends on their ability to work well with men because "...the field is mostly men." She believed she had the attributes required of women to be successful in a male dominated profession.

A New York native, Celine was the youngest of four siblings, but her parents divorced, and her mother's remarriage to her step father included six more siblings - three girls and three boys. Celine spoke of her stepfather, a chemical engineer, as the "biggest influence" on her life and career choices. Celine chose Political Science as her undergraduate major and then started her Masters of Science in Policy Analysis and Management; finishing both at 22 years old. She had several opportunities that broadened her skill set in technology including a consulting job in the Middle East with her step-father who worked for a major fuel industry. Her experiences increased her knowledge in computer set up, networking, and storage. A subsequent position with a major vacation industry was where "I learned to be a Chief Information Officer. I went from being a doer to a team builder with a focus on processes." Celine then continued her growth and development through consulting. 
During this time, she worked with different kinds of businesses and "learned a lot and got a broad view." These experiences not only solidified her personal mission to contribute to an organization but also to use job experiences as vehicles for personal growth. She said, "Every day- every job-consider the value you deliver and what you can learn."

Summer was born in Ohio to Duke University alumni parents. Her mother did not work outside the home and her Dad was in the Navy prior to holding an administrative position in a well-known, national tire organization with an office in a southeastern metropolitan city. She had three brothers, the youngest of whom was ten years older than Summer. She referred to herself as an, "Oops...the only girl and spoiled rotten." Her dad was an inspiration in her life and exposed her to traditionally male hobbies. Tragically, her father died while she was in college. Within a very short period of time, Summer transitioned from a young underclassman to a full-time caregiver and breadwinner.

To make ends meet, Summer took a job as a claims adjuster with a major, national insurance company with an office in her Ohio hometown. Summer eagerly accepted and conquered new leadership challenges by using her experience with adversity to her advantage. When personnel changes in the company prompted an executive to ask Summer to take the Chief Information Officer (CIO) position in the company, she remembered her response as, "Okay, you know I have never done this, [but I] have supported every part of the business, and I love technology, and I know how to bridge the gap, so I'm going to do it." Because Summer has experienced so much hardship, she felt she could relate to others making her an " ... empathetic leader ... people call me the 'People's CIO' because I walk around and I want to know what people are going through... what I can do to help support them."

Margaret was born in Macon, Georgia, but her parents settled in a small town in southeast Georgia near other family. Both of her parents graduated from the University of Georgia. Her dad was a salesman who traveled often, while her mother worked several different education technology leadership roles, including Business Education teacher, student information system coordinator, and, now, a Chief Information Officer for a small education publishing company. Margret graduated with honors from Georgia with a degree in Management of Information Science. After college graduation, she was unsure about her career path. She chose to explore different career options by working for a consulting firm. She landed an opportunity with a large consulting firm which invested in a 12-week leadership program for new employees that exposed her to Dale Carnegie public speaking and business etiquette. Other consultative jobs exposed her to the computing, networking, supply chain, and insurance industries. She finally found a career path when she was encouraged by a male executive to pursue her first technology leadership position with a major insurance organization in 2001. Margaret asserted technology leaders needed a "balance of super techy and soft skills. The strongest CIOs understand both business processes and technology ... the challenge for technology leaders is constant change." She felt that continuous professional development would allow leaders to stay ahead of change.

According to Daiute (2014), constructing a narrative involves "creating meaning and a sense of who they are" (p. 12). These narratives revealed the personality and identity of study participants (Daiute, 2014). Rich, meaningful feedback from participants and my observations created a collective account to make meaning of participant experiences. Daiute's (2014) dynamic narrative inquiry diversity principle along with significance analysis guided the data collection and analysis process. Data was analyzed through the lens of a feminist interpretive framework. Data coding revealed emergent themes. Study credibility and dependability was girded with rich data, triangulation, and member checking, while bias and assumptions were checked through self-reflective memos. The goal was that the female technology leaders participating in the study will find the process enlightening and meaningful. By sharing their experiences, other females may benefit from lessons learned and consider the field.

\section{Results and Discussion}

Participant perception, experiential knowledge, and the study purpose generated the theme of climb your ladder with a sub theme of firm foundation that included the value of role models and mentorship.

\section{Climb Your Ladder}

This theme illustrates how participants overcame discriminatory societal and political barriers as they advanced into powerful positions or titles within their organizations. Eagly and Carli (2007) described the difficult females' career trajectories as not simply climbing a ladder, but rather a tedious process of navigating through a labyrinth with multiple dead ends and challenges that require persistence to successfully traverse. The technology industry is particularly difficult for females as American technology industry recruitment and employment has targeted mostly males (Ashcraft, McLain, \& Eger, 2016; Dermody, 2012; United States Labor Department, 2015; Whitney \& Ames, 2014). Large technology corporations like Google employ $17 \%$ females with technical roles (Whitney \& Ames, 2014, p. 28). All the participants overcame societal and political discriminations by accepting new growth opportunities, facing prejudices, and enduring life challenges in their own unique and persistent ladder climb. 
Female technology leaders are hindered by societal gender role assignments which favored nurturing and predictable career fields, but they overcame the obstacles by accepting new growth opportunities and challenges (Schmidt, 2012; Suter \& Toller, 2006). For Anne, Celine, Summer, and Margaret, challenge was not just something to overcome, but also something they aggressively sought. Each woman shared that if there was nothing new to learn at a company, they would seek another job. All participants in this study worked hard to acquire new skills essential in the rapidly changing technology industry, and realized that in addition to understanding technology, they also needed to be proficient on the business operations of their companies. One participant acknowledged that, "... business and technology are getting so much more intertwined." another equated the importance of business and technology. She stated, “... you can find people that with a technical background, but you need people that can relate to the business and really help drive revenue." Participants reported quitting their jobs if they no longer help advance their careers. One participant shared appreciation of a stimulating working environment "...I learned. I challenged myself; challenged my thinking; challenged what was important to me."

They all shared a passion for learning that stemmed from childhood school success and then continued to increase as they persistently pursued growth opportunities. Female technology leaders were hindered by societal gender role assignments that favored nurturing and predictable career fields, but they overcame the obstacles with a passion for learning in new opportunities, and a growth mindset when faced with challenges.

While each participant faced growth challenges in her job, they also faced inherent political challenges associated with workplace gender discrimination. One participant faced resentment for simply being a woman in technology leadership. Anne shared her struggles traversing a hostile work environment where she had to "... work harder, be better, know more, outthink him and outsmart him." Other participants faced discrimination for simply being pregnant and often resorted to hiding the pregnancies to avoid exclusion from workplace projects. Several researchers have found that some women hide their pregnancies as a strategy to remain viable in their position especially in fields like technology and engineering (Harris \& Giuffre, 2010; Powell \& Sang, 2015). Celine and Summer reported unequal gender representation in technology leadership which is supported by national statistics that indicated 6\% female participation in technology leadership (Ashcraft, McLain, \& Eger, 2016; Harvey Nash CIO Survey, 2015; United States Labor Department, 2015). Sallie said, "The biggest challenge has been when I moved into a role [previously held by a man] and not given the recognition that I'm doing that role until I've proved myself." Each of them addressed these challenges with the notion that persistence, in spite of politically discriminatory practices, insured their success.

While participants faced external barriers associated with societal gender role assignments and political discrimination, they also faced internal struggles steeped in societal expectations for maintaining a balance between their work and life. This was a deeply personal struggle - different for each participant - that required each of them to be more creative with constraints and better with building boundaries centered on knowing when it is time to plow forward in their careers and when it was time to shift their priorities at home. With each decision, participants had to be self-assured that it was acceptable to make work and life balance choices that may not match societal expectations for women. Celine did not allow the roles of 'mom' or 'wife' to be excuses for not moving to the top. She pushed the boundaries of societal expectations for a woman and moved away from her daughters to follow her career path. In the process, she and her daughters redefined the role of 'mom' and found their own happy balance on their own terms and not by society's standards. She said, "I've had to make some huge trade-offs between family and career to be in this position... and I think that's part of the challenge."

On the other hand, Summer quit college and changed her career on several occasions to be the primary caregiver to one of her family members. Despite choosing family over career, Summer landed the role of Chief Information Officer in a major organization. She said, "I have a very strong faith, a personal relationship with God, my husband is my second priority, my children, my family... my job is a means to an end." Margaret proved to be a true picture of work and life balance as she and her husband supported each other in their career goals. She said, "I've done it. I have a good marriage and I have two kids that know me and I'm involved and care about their lives. I have had to sacrifice ... there are gives and takes on both sides." Each of the participants did not let life challenges stop them; they simply climbed their ladder another way, which allowed them to stay true to the moms, wives, sisters, daughters, business women, and friends they wanted to be. Overall, support systems for women who desire a balance of work and family life do not exist in the time-consuming technology sector (Cukier, 2009).

\section{Firm Foundation}

Most of the study participants cited a father as a primary influence in their life which ultimately provided a firm foundation for each of them as they climbed their ladders. Margaret's father died when she was still in high school, but she said she was motivated by wanting to "make her dad proud." Each of them said they felt supported, encouraged, or guided by a father figure which ultimately gave them the confidence to succeed in a male dominated career path. Most of them also cited male mentors on the job who sustained them in their careers. In fact, Summer advised upcoming female technologists to seek out a male advocate since the technology was still male dominated. 
The message here is that supportive men are an important ingredient in success for females in technology. However, Celine and Margaret both reported strong female mentors who encouraged them along their path. For participants, mentorship is not dictated by gender.

Richman et al., (2011) indicated female role models allow girls considering a high-tech field to overcome feelings of inadequacy. Aligned with this advice, all of the participants are heavily involved in mentorship opportunities with other women and young girls considering the field of technology. According to Grace, "The most important thing is to be able to find a mentor ... They say that eight out of 10 men [have mentors] and only 3 out of every 10 women have a [mentor]." Grace has leveraged her company funding to start a scholarship for disadvantaged girls who have interest and skills in science, technology, engineering, and mathematics. Lisa mentors through an organization called, Pathfinders that partners her with another female technologist for an entire year while Margaret mentors young alumni from the University of Georgia. Celine reported several mentorship experiences, but she also stated she often learns from the young people she mentors because "... everybody has value."

The climb your ladder theme showed how the participants overcame societal and political discriminations by accepting new growth opportunities, facing prejudice, and enduring life challenges through persistence. The sub theme of firm foundation portrayed the participants' strong father figures, male mentors, and female role models as important influencers in their lives.

\section{Conclusions and Implications}

The experiences of females who participated in this study support the notion that women in technology roles experience social, political and emotional issues because of their gender. Their views may be considered to bridge the technology field gender divide and decrease disproportionality. This study's results demonstrate the problems of inequality still exist. According to Demaiter and Adams (2009), the female technology leader should be aware of gender disproportionality so that she leverages her influence to affect change. By participating in this study and with the mentoring work each of them is committed to accomplish, female technology leaders featured in this study exceeded the standard for female technology leaders helping other female technology leaders.

This study illuminated five female technology executives' experiences to and revealed the social, political, and emotional barriers they faced in their technology career trajectories. Barriers include societal gender role assignments, discriminatory exclusions, and bias against female specific issues like pregnancy and life demands. With encouragement from their dads, participants worked their way to a Chief level position in the highly competitive technology field dominated by men. Personality traits like the desire for challenge, ability to persevere, urge to be assertive, and the courage to discover a new path kept them pushing forward. They overcame barriers in the industry by accepting new growth opportunities, facing prejudice, and enduring life challenges through persistence.

Despite limitations, study results may benefit females who are considering the technology field. The findings may aid the United States Department of Education, state educational agencies, university systems, school districts, and counselors at all levels in efforts to promote female participation in technology.

The study findings provide knowledge that may assist American technology industries in their efforts to recruit, train, and promote more females in technology positions, resulting in opening the talent base for skilled American technologists. Study findings can benefit workplace culture by revealing practices technology organizations can employ and policies they can include to remove barriers for females so they can consider technology as a viable and rewarding career.

Possible future research opportunities developed through the course of data analysis. First, a larger sample would provide even more information to strengthen study findings and conclusions. Second, a similar study focused on a specific minority ethnicity would illuminate issues specific to racial and gender barriers. Third, a study focused in a different metropolitan city would provide comparative data to ensure study results are transferable. In fact, a study which included an international sample would bring to light issues that face females in technology around the world.

It may also be beneficial to include the perspective of males regarding female leaders in technology. Since each of the participant pointed to a strong male role model, inclusion of the male perception may point to unknown barriers and strategies to overcome them. It may also be beneficial to interview subordinates who serve under female technology leaders regardless of gender. 


\section{References}

Alstott, A. (2014). Gender quotas for corporate boards: Options for legal design in the united states. Faculty Scholarship Series. Retrieved from http://digitalcommons.law.yale.edu/fss_papers/4868

Armani, S. (2013). The gender wage gap in the United States: Current policy and an improved approach for closing the gap. Student Pulse, 5(06), 1-4. Retrieved from

http://www.inquiriesjournal.com/articles/739/the-gender-wage-gap-in-the-united-states-currentpolicy-and-an-improved-approach-for-closing-the-gap

Ashcraft, C., McLain, B., \& Eger, E. (2016). Women in tech: The facts. Retrieved from

https://www.ncwit.org/sites/default/files/resources/womenintech_facts_fullreport_05132016.pdf

Autio, O. (2013). When talent is not enough: Why technologically talented women are not studying technology. Journal of Technology Education. 24(2), 14-30. doi:10.21061/jte.v24i2.a.2

Beckhusen, Julia, Occupations in information technology. American Community Survey Reports, ACS-35, U.S. Census Bureau, Washington, DC, 2016. Retrieved from https://www.census.gov/content/dam/Census/library/publications/2016/acs/acs-35.pdf

Belenky, M. (1986). Women's ways of knowing: The development of self, voice, and mind. New York: Basic Books.

Belenky, M., Clinchy, B., Goldberger, N., \& Tarule, J. (1997). Women's ways of knowing. The development of self, voice, and mind. New York: Basic Books.

Berkery, E., Tiernan, S., \& Morley, M. (2013). The relationship between gender role stereotypes and requisite managerial characteristics: The case of nursing and midwifery professionals. Journal of Nursing Management, 22(6), 707-719. doi:10.1111/j.1365-2834.2012.01459.x

Bessen, J. (2014). Employers aren't just whining - The skills gap is real. Retrieved from

https://hbr.org/2014/08/employers-arent-just-whining-the-skills-gap-is-real

Bierema, L. \& Cseh, M. (2003). Evaluating AHRD research using a feminist research framework: a longitudinal study. Human Resource Development Quarterly, 14(1). Retrieved from

http://library.valdosta.edu:2048/login?url=http://search.ebscohost.com/login.aspx?direct=true\&db=bth\&AN= $11578757 \&$ site $=$ eds-live $\&$ scope $=$ site

Bloom, L. (1996). Stories of one's own: Nonunitary subjectivity in narrative representation. Qualitative Inquiry, 2 (2), 176-197. doi: 10.177/107780049600200203

Bluestein, G. (2015). Skilled workers needed. Retrieved from http://www.ajc.com/news/local-education/skilled-workers-needed/AFXQ2eEKg7H4AZelz0CYYP/

Brumels, K., \& Beach, A. (2008). Professional role complexity and job satisfaction of collegiate certified athletic trainers. Journal of Athletic Training, 43(4), 373-378. Retrieved from

http://library.valdosta.edu:2048/login?url=http://search.ebscohost.com/login.aspx?direct=true\&db=psyh\&AN $=2008-11317-002 \&$ site $=$ eds-live \&scope $=$ site

Bumiller E. \& Shanker, T. (2013). Pentagon is set to lift combat ban for women. Retrieved from

http://www.nytimes.com/2013/01/24/us/pentagon-says-it-is-lifting-ban-on-women-in-combat.html

Butler, J. (1990). Gender trouble: Feminism and the subversion of identity. New York: Routledge, 1990.

Carlson, J., \& Ray, R. (n.d.). Feminist theory. Oxford Bibliographies Online Datasets.

doi:10.1093/obo/9780199756384-0020

Cech, E. A., \& Blair-Loy, M. (2010). Perceiving glass ceilings? Meritocratic versus structural explanations of gender

inequality among women in science and technology. Social Problems, 57(3), 371-397.

doi:10.1525/sp.2010.57.3.371

Cejka, M. \& Eagly, A. (1999). Gender-stereotypic images of occupations correspond to the sex segregation of employment. Personality and Social Psychology Bulletin, 25, 413-423. doi: $10.1177 / 0146167299025004002$

Chang, Andrea (2010). Toy fair 2010: After strong holiday sales, Barbie flaunts new jobs and fashions. (2010, February 14). The Los Angeles Times. Retrieved from http://latimesblogs.latimes.com/money_co/2010/02/toy-fair-2010-mattel-strong-holiday-sales-barbieflaunts-new-jobs-and-fashions.html

Cheryan, S., Plaut, V., Handron, C., Hudson, L. (2013). The stereotypical computer scientist: Gendered media representations as a barrier to inclusion for women. Sex Roles, 69(1-2), 58-71. doi:10.1007/s11199-0130296-x 
Chou, Y., Yen, H., \& Sun, C. (2012). An integrate method for performance of women in science and technology based on entropy measure for objective weighting. Quality \& Quantity Qual Quant, 48(1), 157-172. doi:10.1007/s11135-012-9756-6

Civil Rights Act of 1964 § 7, 42 U.S.C. § 2000e et seq (1964).

Clandinin, D.J., \& Murphy, S. (2007). Looking ahead: Conversations with Elliot Mishler, Don Polkinghorne, and Amia Lieblich. In Clandinin, D.J. (ed.) Handbook of narrative inquiry: Mapping a methodology. Pp 632650. Thousand Oaks, CA: Sage Publications.

Code, L. (2000). Encyclopedia of feminist theories. London: Routledge.

Corporate ladder. (n.d.). Dictionary.com unabridged. Retrieved from

http://wwww.dictionary.com/browse/corporae-ladder

Cosell, B. \& Urlich, J. (2009). Handbook on gender roles: Conflicts, attitudes, and behaviors. New York: Nova Science Publishers, Inc.

Cozzens, S. E. (2008). Gender issues in US science and technology policy: Equality of what? Science and Engineering Ethics, 14(3), 345-356. doi:10.1007/s11948-008-9061-x

Cukier, W. (2009). Attracting, retaining and promoting women. Best practices in the Canadian tech sector. Ottawa: Canadian Advanced Technology Alliance.

Cunningham, C. M. (2015). "Men are like bluetooth, women are like wi-fi": What feminist technology studies can add to the study of information and communication technologies. The Northwest Journal of Communication, 43(1), 7-21. Retrieved from

http://library.valdosta.edu:2048/login?url=http://search.ebscohost.com/login.aspx?direct=true\&db=uf h\&AN=101054565\&site $=$ eds-live \&scope $=$ site

Cyberstates 2017. (2017). Cyberstates 2017. The definitive national, state, and city analysis of the U.S. tech industry and tech workforce. Retrieved from http://www.cyberstates.org/pdf/CompTIA\%20Cyberstates\%202017.pdf

Davenport, T. (2016). No one wants to be a chief information officer anymore. Retrieved from http://fortune.com/2016/03/10/why-no-one-wants-to-be-a-chief-information-officer-any-more/

Demaiter, E., \& Adams, T. L. (2009). "I really didn't have any problems with the male-female thing until...": Successful womens' experiences in IT organizations. Canadian Journal of Sociology, 34(1), 31-53. Retrieved from http://library.valdosta.edu:2048/login?url=http://search.ebscohost.com/login.aspx?direct=true\&db=e $\mathrm{db} \& \mathrm{AN}=40310030 \&$ site $=$ eds-live \&scope $=$ site

Dermody, K. (2012). Sexism in the tech industry. Retrieved from http://www.lieffcabraser.com/employment/sexism-in-tech/

De Welde, K., Laursen, S., \& Thiry, H. (2007). SWS fact sheet: Women in science, technology, engineering and math (STEM). Network News: The Newsletter for Sociologists for Women in Society 23(4), 1419. Retrieved from

http://socwomen.org/fact-sheets

DuBow, Wendy M., Farmer, Ruthe., Wu, Zhen,, \& Fredrickson, Malia. (2015). Viewpoints. 56(12), 34-37. doi: $10.1145 / 2535917$

Dugan, J. P., Fath, K. Q., Howes, S. D., Lavelle, K. R., \& Polanin, J. R. (2013). Developing the leadership capacity and leader efficacy of college women in science, technology, engineering, and math Fields. Journal of Leadership Studies, 7(3), 6-23. doi:10.1002/j1s.21292

Eagly, A. (1987). Reporting sex differences. American Psychologist, 42(7), 756-757. Doi: 10.1037/0003006X42.7.755

Eagly, A. \& Carli, L. (2007). Through the labyrinth: The truth about how women become leaders. Boston, MA:

Harvard Business School Press.

Eagly, A. \& Karau, S. (2002). Role congruity theory of prejudice toward female leaders. Psychological Review, 109(3), 573-598. Retrieved from

http://library.valdosta.edu:2048/login?url=http://search.ebscohost.com/login.aspx?direct=true\&db=pdh\&AN= 2002-13781-007\&site=eds-live \&scope $=$ site

Equal Pay Act of 1963 - EPA - 29 U.S. Code Chapter 8 § 206(d).

Executive Alliance. (2015). Proceedings from women in technology summit. Women's Legacy. Amelia Island, FL.

Fatemi, F. (2017). 5 U.S. cities poised to become tomorrow's tech meccas. Retrieved from https://www.forbes.com/sites/falonfatemi/2017/03/23/5-u-s-cities-poised-to-become-tomorrowstech-meccas/ 
Fifty Years after the Equal Pay Act, National Equal Pay Task Force. (2013). Report of the National Equal Pay Task Force. Retrieved from

https://www.whitehouse.gov/sites/default/files/image/image_file/equal_paytask_force_progress_report_june_10_2013.pdf

Fritsch, N. (2015). At the leading edge-does gender still matter? A quantitative study of prevailing obstacles and successful coping strategies in acadamia. Current Sociology, 63(4), 547. doi:10.1177/0011392115576527

Galvan, J. L. (2014). Writing literature reviews: A guide for students of the social and behavioral sciences (6th ed.). Los Angeles, CA: Pyrczak.

Gettings, J., Johnson, D., Brunner, B., \& Franz, C. (2007). Wonder women. Profiles of leading female CEOs and business executives. Retrieved from https://www.infoplease.com/wonder-women

Goldin, C. (2006). The quiet revolution that transformed women's employment, education, and family. AEA Papers and Proceedings, 96(2). doi: 10.1257/000282806777212350

Gray, M., Agllias, K., \& Schubert, L. (2015). Doctoral research from a feminist perspective: Acknowledging, advancing and aligning women's experience. Qualitative Social Work,14(6), 758-775.

doi: 10.117 .1473325014565148

Griffith, E. (2015). The top technology companies of the fortune 500. Retrieved from http://fortune.com/2015/06/13/fortune-500-tech/

Gross, R. (2003). What went wrong? Feminism and freedom from the prison of gender roles. Cross Currents. 53(1), 8-20.

http://library.valdosta.edu:2048/login?url=http://search.ebscohost.com/login.aspx?direct=true \&db=e db\&AN $=9868315 \&$ site $=$ eds-live $\&$ scope $=$ site

Gross, S. (2013). 22 countries outrank the U.S. in gender equality-Take the lead. Retrieved from http://www.taketheleadwomen.com/blog/propel-take-the-lead-drives-change/parity/22-co

Grosz, E. (2010). The practice of feminist theory. Differences: A journal of feminist cultural studies, 21(1), 94-108. doi: 10.1215/1040 7391-2009-019

Hampton, A. McGowan, P. \& Cooper, S. (2011). Developing quality in female high-technology entrepreneurs' networks. International Journal of Entrepreneurial Behaviour \& Research, 17(6), 588606. Retrieved from http://dx.doi.org/10.1108/13552551111174684

Harris, D. \& Giuffre, P. (2010). The price you pay. How female professional Chefs negotiate work and family. Gender Issues, 27(1/2). 27. doi: 10.1007/s12147-010-9086-8

Harvey Nash CIO Survey. (2015). Retrieved from http://www.harveynash.com/group/mediacentre/Harvey_Nash_CIO_Survey_2015.pdf

Hellerstein, J. \& Morrill, M. (2011). Dads and daughters: The changing impact of fathers on women's occupational choices. Journal of Human Resources, 46(2), 333-372. Retrieved from:

https://login.ezproxy.library.valdosta.edu/login?url=http://search.ebscohost.com/login.aspx?direct=tr ue $\& \mathrm{db}=$ eric $\& A N=E J 944346 \&$ site $=$ eds-live $\&$ scope $=$ site

Henning, J.M., \& Weidner, T.G. (2008). Role strain in collegiate athletic training approved clinical instructors. Journal of Athletic Training, 43(3), 275-283. Retrieved from

http://library.valdosta.edu:2048/login?url=http://search.ebscohost.com/login.aspx?direct=true\&db=rz h\&AN=105780974\&site $=$ eds-live \&scope $=$ site

Henry, R. L. (2015). Moving from theory to practice: Incorporating feminist approaches into search and discovery tool development. The Journal of Academic Librarianship, 41(4), 514-516. doi:10.1016/j.acalib.2015.06.020

Hickey, W. (2013). Americans won't like hearing the real reason that Silicon Valley is pushing so hard for immigration reform. Retrieved from

http://www.businessinsider.com/the-real-truth-about-the-stem-shortage-that-americans-dont-want-to-hear2013-5

Hogg, M. A., \& Knippenberg, D. v. (2003). Leadership and power: Identity processes in groups and organizations. London: SAGE Publications Ltd.

Ibarra, H. \& Obodaru, O. (2009). Women and the vision thing. Human Resource Management International Digest, (4), doi:10.1108/hrmid.2009.04417dad.001

Jackson, S. M., Hillard, A. L., \& Schneider, T. R. (2014). Using implicit bias training to improve attitudes toward women in STEM. Social Psychology of Education, 17(3), 419-438. doi:10.1007/s11218-0149259-5

Karkaria, U. (2013). GM to invest \$26M, hire 1K at Atlanta IT center. Retrieved from http://www.bizjournals.com/atlanta/blog/atlantech/2013/01/gm.html?page=all 
Kuruvilla, J. (2014, June 24). News Release. Retrieved from http://www.dol.gov/opa/media/press/eta/ETA20141177.htm

Kuther, T. L., \& McDonald, E. (2004). Early adolescents' experiences and views of barbie. Adolescents,39(153). 39-51. Retrieved from http://library.valdosta.edu:2048/login?url=http://search.ebscohost.com/login.aspx?direct=true\&db=si $\mathrm{h} \& \mathrm{AN}=17713348 \&$ site $=$ eds-live $\&$ scope $=$ site

Layne, L. L., Vostral, S. L., \& Boyer, K. (eds.) (2010). Feminist technology. Urbana: University of Illinois Press.

Lily Ledbetter Fair Pay Restoration Act of 2009. Section 706(e) of the Civil Rights Act of 1964 (42 U.S.C. 2000e-5(e)).

Lorenz, T. (2014). Barbie book titled 'I can be a computer engineer' tells girls they need a man's help to code.

Retrieved from http://www.businessinsider.com/barbie-book-tells-girls-they-need-a-mans-help-tocode-2014-11

Lorre, C., Prady, B., Collier, M., Belyeu, F. O., Cohen, R., Goetsch, D., \& Molaro, S. (2008). The big bang theory: The complete first season. Warner Home Video (Firm). Burbank, CA: Distributed by Warner Home Video.

Lublin, D. \& Brewer, S. (2003). The continuing dominance of traditional gender roles in southern elections. Social Science Quarterly, (2), 379. doi: 10.1111/1540-6237.8402010

Manley, K. (2009). The bfoq defense: Title VII's concession to gender discrimination. Duke Journal of Gender Law \& Policy, 16(196), 169-210. Retrieved from http://library.valdosta.edu:2048/login?url=http://search.ebscohost.com/login.aspx?direct=true \&db=si $\mathrm{h} \& \mathrm{AN}=36658456 \&$ site $=$ eds-live $\&$ scope $=$ site

Martin, P. \& Barnard, A. (2013). The experience of women in male-dominated occupations: A constructivist grounded theory inquiry. SAJIP: South African Journal of Industrial Psychology, 39(2), 1-12. doi:10.4102/sajip.v39i2.1099

Mattel says it erred; Teen talk Barbie turns silent on math. (1992, October 21). The New York Times. Retrieved from http://www.nytimes.com/1992/10/21/business/company-news-mattel-says-it-erredteen-talk-barbie-turns-silent-on-math.html.

Maxwell, J. (1991). Developing Highly Effective Leaders. EL Cajon, CA: INJOY.

Maxwell,J. (2013). Qualitative research design: An interactive approach (3rd ed.). Thousand Oaks, CA: Sage Publications.

McEldowney, R.P., Bobrowski, P. \& Gramberg, A. (2009). Factors affecting the next generation of women leaders: Mapping the challenges, antecedents and consequences of effective leadership. Journal of Leadership Studies, 3(2), 24-30. http://dx.doi.org/10.1002/j1s.20105

Mehravari, N. (2016). Structuring the chief information security officer (CISO) organization. Retrieved from https://insights.sei.cmu.edu/sei_blog/2016/02/structuring-the-chief-information-security-officer-cisoorganization.html

Milgram, D. (2011). How to recruit women and girls to the science, technology, engineering, and math (STEM) Classroom. Technology and Engineering Teacher, (11), 4-8. Retrieved from http://library.valdosta.edu:2048/login?url=http://search.ebscohost.com/login.aspx?direct=true \&db=tf $\mathrm{h} \& \mathrm{AN}=67074361 \&$ site $=$ eds-live $\&$ scope $=$ site

Miller, C. (2013, October 5). Curtain is rising on a tech premiere with (as usual) a mostly male cast. New York Times, p. 1. Retrieved from http://nyti.ms/1968L3K

Miller, G. (2004). Frontier masculinity in the oil industry: The experiences of women engineers. Gender, Work and Organization,11(1):47-73. doi:10.1111/j.1468-0432.2004.00220.x

Miller, Z. (2016). Hillary Clinton: Madeleine Albright speaks in New Hampshire. Retrieved from http://time.com/4210769/hillary-clinton-madeleine-albright-new-hampshire/

Mishler, E. (1979). Meaning in context: Is there any other kind? Harvard Educational Review, 49(1), 1-19. Retrieved from

http://library.valdosta.edu:2048/login?url=http://search.ebscohost.com/login.aspx?direct=true \&db=er ic \&AN=EJ202774\&site $=$ eds-live \&scope $=$ site

Morelli, C. (2015). Women's issues in the Obama era: expanding equality and social opportunity under the Obama administration. Student Pulse. 7(02), 1-3. Retrieved from http://www.inquiriesjournal.com/articles/992/womens-issues-in-the-obama-era-expanding-equalityand-social-opportunity-under-the-obama-administration

Moye, J. J. (2016). The supply and demand of technology and engineering teachers in the United States: Who knows? Technology \& Engineering Teacher, 76(4), 32-37. 
http://library.valdosta.edu:2048/login?url=http://search.ebscohost.com/login.aspx?direct=true\&db=tfh\&AN=1 $19717556 \&$ site $=$ eds-live $\&$ scope $=$ site

Orser, B., Riding, A., \& Stanley, J. (2012). Perceived career challenges and response strategies of women in the advanced technology sector. Entrepreneurship \& Regional Development, 24(1-2), 73-93.

doi: http://dx.doi.org/10.1080/08985626.2012.637355

Paustian-Underdahl, Walker, \& Woehr, (2014). Gender and perceptions of leadership effectiveness: A metaanalysis of contextual moderators. The Journal of Applied Psychology, 99(6), 1129-1145. doi: $10.1037 / \mathrm{a} 0036751$

Perry, J. L., (Ed.). (2010). The Josey-Bass reader on non-profit and public leadership. San Francisco, CA: Josey-Bass Publishing.

Powell, A., Dainty, A., \& Bagilhole, B. (2012). Gender stereotypes among women engineering and technology students in the UK: Lessons from career choice narratives. European Journal of Engineering Education, 37(6), 541-556. Retrieved from http://www.tandfonline.com/doi/abs/10.1080/03043797.2012.724052

Powell, A., \& Sang, K. (2015). Everyday experiences of sexism in male-dominated professions: a bourdieusian perspective. Sociology, 49(5). 919-936. Retrieved from http://library.valdosta.edu:2048/login?url=http://search.ebscohost.com/login.aspx?direct=true\&db=p syh \&AN=2015-46032-008\&site=eds-live $\&$ scope $=$ site

Pujol, J., \& Montenegro, M. (2015). Technology and feminism: A strange couple. Revista de Estudios Sociales, (51), 173-185. doi: http://dx.doi.org/10.7440/res51.2015.13.

Ravitch, S. M., \& Riggan, M. (2012). Reason \& rigor: How conceptual frameworks guide research. Thousand Oaks, CA: Sage Publications.

Ravitz, J. (2015, April 16). Women in the world: where the U.S. falters - CNN.com. Retrieved from http://www.cnn.com/2015/04/16/us/american-women-world-rankings/index.html

Richman, L. S., Vandellen, M., \& Wood, W. (2011). How women cope: Being a numerical minority in a male-dominated profession. Journal of Social Issues, 67(3), 492-509. doi:10.1111/j.1540-4560.2011.01711.x

Rodriguez, S. (2017). Why tech companies need immigrants to function. Retrieved from https://www.inc.com/salvador-rodriguez/why-tech-needs-immigrants.html

Roehrig, G., Tamara, M., Hui-Hui, W., \& Mi Sun, P. (2012). Is adding the E enough? Investigation the impact of K-12 engineering standards on the implementation of STEM integration. School Science and Mathematics, 112(1), 31-44. doi:10.11.11/j.1949-8594.2011.00112.x

Rosser, S. (2005). Through the lenses of feminist theory: Focus on women and information technology. Frontiers: A Journal of Women Studies, 26(1), 1-23. doi: 10.1353/fro.2005.0015

San Miguel, R., \& Roeder, K. (2016). Atlanta outpaces nation in tech talent growth. Retrieved from https://hypepotamus.com/news/tech-talent-report/

Saucerman, J., \& Vasquez, K. (2014). Psychological barriers to STEM participation for women over the course of development. Adultspan Journal, 13(1), 46-64. doi:10.1002/j.2161-0029.2014.00025.x

Sayer, L. (2014). Trends in women's and men's time use, 1965-2012: Back to the future? Gender and Couple Relationships. Pennsylvania State University National Symposium on Family Issues, Springer. Retrieved from http://www.timeuselab.umd.edu/uploads/1/8/7/9/18797564/sayer_ch2_nsfi.pdf

Schmidt, S. J. (2012). Am I a woman? The normalization of woman in US History. Gender and Education, 24(7), 707-724. doi:10.1080/09540253.2012.674491

Sen, A.K. (1992). Inequality reexamined. Oxford: Oxford University Press.

Shakeshaft, C. (1999). The struggle to create a more gender inclusive profession. In J. Murphy \& C.S. Lewis (Eds.), Handbook of Research on Educational Administration (2nd ed., pp. 99-118). San Francisco: Jossey-Bass.

Should Congress Pass S. 2199, The Paycheck Fairness Act? (2014). Congressional Digest, 93(5), 14, p. 14-31. Retrieved from: http://library.valdosta.edu:2048/login?url=http://search.ebscohost.com/login.aspx?direct=true \&db=ul h\&AN=95883190\&site $=$ eds-live \&scope $=$ site

Siniscalco, G. Damrell, L., \& Nabity, C. (2014). The pay gap, the glass ceiling, and pay bias: Moving forward fifty years after the Equal Pay Act. ABA Journal of Labor \& Employment Law, 29(3), 395-427. Retrieved from http://library.valdosta.edu:2048/login?url=http://search.ebscohost.com/login.aspx ?direct=true \&db=bt $\mathrm{h} \& \mathrm{AN}=102906840 \&$ site $=$ eds-live \&scope $=$ site 
Sipe, S., Johnson, C. D, \& Fisher, D. (2009). University students' perceptions of gender discrimination in the workplace: Reality versus fiction. Journal of Education for Business. 84(6), 339-349. Retrieved from https://eric.ed.gov/?id=EJ844513

Smyth, F. L. \& Nosek, B.A. (2015). On the gender-science stereotypes held by scientists: Explicit accord with gender-ratios, implicit accord with scientific identity. Frontiers in Psychology, 6(415), 1-19. Retrieved

from http://library.valdosta.edu:2048/login?url=http://search.ebscohost.com/login.aspx?direct=true\&db=e dsdoj\&AN=edsdoj.8b5a4255e714ee5a3907d4379cb934a\&site=eds-live\&scope=site

Stephens, A., Jacobson, C., \& King, C. (2010). Describing a feminist-systems theory. Systems Research and Behavioral Science, 27(5), 553-566. doi:10.1002/sres.1061

Stoller, K. (2017). The world's largest tech companies 2017: Apple and Samsung lead, followed by Facebook. Retrieved from https://www.forbes.com/sites/kristinstoller/2017/05/24/the-worlds-largest-techcompanies-2017-apple-and-samsung-lead-facebook-rises/\#17f9e200d140

Suter, E. \& Toller, P. (2006). Gender role and feminism revisited: A follow-up study. Sex Roles, 55(1-2), 135146. doi: 10.1007/s11199-006-9065-4

Talent Shortage Survey - ManpowerGroup. (2016). Retrieved from http://www.manpowergroup.com/talentshortage-explorer/\#.WXAG4YTyupo

Tripathy, A. (2017). The future of American jobs lies with the tech industry. Retrieved from

https://techcrunch.com/2017/01/27/the-future-of-american-jobs-lies-with-the-tech-industry/

Trubey, J. S. (2016). Tech square v. 2 could supercharge midtown. Retrieved from http://www.myajc.com/business/tech-square-could-superchargemidtown/2vgE62ugJb71 as38fPydaN/

The White House, Office of the Press Secretary. (2015). Fact sheet: The Equal Futures Partnership-Progress to expand women's economic and political participation and enhance information sharing and lessons learned [Press release]. Retrieved from https://www.whitehouse.gov/the-press-office/2015/09/08/fact-sheet-equal-futures-partnershipprogress-expand-women\%E2\%80\%99s-economic

United States Department of Labor. Bureau of Labor Statistics. (2015, December). BLS reports: Women in the labor force: a data book. Retrieved from http://www.bls.gov/opub/reports/womensdatabook/archive/women-in-the-labor-force-a-databook-2015.pdf

Watts, J. (2007). Can't take a joke? Humor as resistance, refuge and exclusion in a highly gendered workplace. Feminism and Psychology. 52(s2): 211-223. doi: http://dx.doi.org/10.1177\%2F0959353507076560

Wentling, R., \& Thomas, S. (2009). Workplace culture that hinders and assists the career development of women in information technology. Information Technology, Learning and Performance Journal, 25(1), 25-42. Retrieved from

http://library.valdosta.edu:2048/login?url=http://search.ebscohost.com/login.aspx?direct=true \&db=a qh $\& A N=46800519 \&$ site $=$ eds-live $\&$ scope $=$ site

Whitney, T., \& Ames, E. (2014). Innovation and inclusion. Communications of the ACM Commun. ACM, 57(12), 28-30. doi:10.1145/2676861

Wood, C. (2016). What is a chief technology officer? Retrieved from http://www.govtech.com/people/WhatIs-a-Chief-Technology-Officer.html

Wood, W. \& Eagly A. (2012). Biosocial construction of sex differences and similarities in behavior. In M. P. Zanna \& J. M. Olson (Eds.), Advances in Experimental Social Psychology. San Diego, CA: Academic Press.

Zweben, S., \& Bizot, B. (2016, May). Taulbee Survey. Retrieved from http://cra.org/wp-content/uploads/2016/05/2015-Taulbee-Survey.pdf 